\title{
STRATEGIC ANALYSIS OF GLOBAL E-COMMERCE AND DIVERSIFICATION TECHNOLOGY: THE CASE OF AMAZON.COM INC.
}

\author{
Irina V. Onyusheva \\ Tanatthon Seenalasataporn \\ Stamford International University, Bangkok, Thailand
}

This paper considers the strategical issues of the Amazon.com development, presenting in detail the strategic analysis of external and internal business environment of this company in its current situation, suggesting also the alternative strategy for the future.

Keywords: E-commerce, technology, diversification, strategy, globalization, Amazon.com

\section{Introduction}

Strategy is significant execution plan for business through the individual level which brings up or down depending on the environment and analysis of the related factors. The catalyst would come from internal and external environments, both having direct and indirect impact on businesses. That is why strategy is supposed to combine critical thinking with exploratory analysis and detailed investigation.

Amazon is a global corporation which is ranked 12th in the Fortune full list with the latest data on revenues being $\$ 135,987$ Million (Fortune 500, 2016). Amazon was established

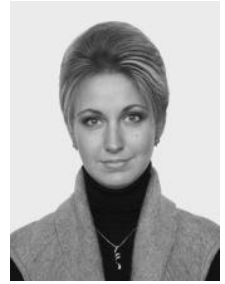

Irina V. Onyusheva

$\mathrm{PhD}$ in Economics, Dr.h.c. of IANH, Associate Professor, Corresponding Member of Academy of Pedagogical Sciences of Kazakhstan, Academician of International Informatization Academy, member of the Editorial Board of the 'Polish Journal of Management Studies' (Scopus, SJR, WoS).

Research Field And Scientific Interests: formation, ensuring and increasing economic competitiveness on both micro- and macro- levels; human capital development; HR management; knowledge economy; project management.

She is the author of more than 70 research publications, author of an individual scientific monograph named "Human capital in context of national economic competitiveness: formation factors and development prospects» (2015) awarded as "Best educational edition in economic field" in the framework of the XXVI international book fair of educational publications (Sochi, Russia, October 8-11, 2015), and Gold medal "European Quality" (ESIC, Germany, Russia, April 4, 2016).

E-mail: irina.onyusheva@stamford.edu

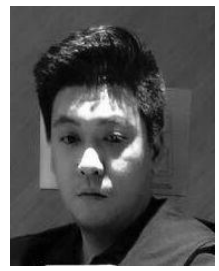

Tanatthon Seenalasataporn

Stamford International University, International MBA Program

Interests - Strategic Management, Project Management, E-Commerce, Diversification Technology

E-mail: 316331005@students.stamford.edu 
back in 1994 from Amazon.com book by Jeff Bezos with the investment of only \$10,000. The Bezos's message was then described as "Amazon.com strives to be the e-commerce destination where consumers can find and discover anything they want to buy online" (Kotelnikov, 2008). Currently, Amazon has the market capital of 427 bln USD (Fortune 500, 2017).

This work aims to illustrate and analyze Amazon in its various dimensions of business operations and its market segmentation by focusing on its current business model and strategy.

\section{Company's Current Strategy}

\section{Overview of Amazon.Com With its Current Business Units}

Amazon.com is a corporation which was essentially global in nature, from the initial stage of its development and until now. Moreover, Amazon diversifies greatly its business strategy, thus providing a lot of meaningful information for potential research.

\section{Current Vision, Mission and Goals}

CEO Jeff Bezos released the latest annual letter to shareholders, explaining the business drivers of Amazon.com Inc. Those were described under 3 themes of high velocity decisions. Firstly, any decision can be undone, as it is argued by Amazon's CEO that "If you walk through and don't like what you see on the other side, you can't get back to where you were before. We can call these Type 1 decisions. But most decisions aren't like that - they are changeable, reversible - they're two-way doors" (Gupta, 2017).

Table 1. Amazon.com's vision \& mission statement

\begin{tabular}{|c|c|}
\hline Visions statement & $\begin{array}{c}\text { To be the Earth's most customer-centric company, where customer can } \\
\text { find and discover anything they might want to buy online }\end{array}$ \\
\hline $\begin{array}{c}\text { Mission } \\
\text { statement }\end{array}$ & $\begin{array}{r}\text { To strive to offer our customers the lowest possible price, the best } \\
\text { available selection and the utmost convenience }\end{array}$ \\
\hline Goals & $\begin{array}{c}\text { To move quickly to solidify and extend our current position while we } \\
\text { begin to pursue the online commerce opportunities in other areas. We } \\
\text { see substantial opportunity in the large markets we are targeting. This } \\
\text { strategy is not without risk: it requires serious investment and crisp } \\
\text { execution against established franchise leaders. }\end{array}$ \\
\hline
\end{tabular}

Secondly, disagree and commit with yourself, this is described as "If you have conviction on a particular direction even though there's no consensus, it's helpful to say, "Look, I know we disagree on this but will you gamble with me on it? Disagree and commit?" (Gupta, 2017).

Thirdly, act with 70\% information (Gupta, 2017). Businesses should take action even having only $70 \%$ of information, thus choosing to start faster rather than wait for the information to be complete. This indirectly shows how much more competitive Amazon.com is at today's market. 


\section{STRATEGIC ANALYSIS OF GLOBAL E-COMMERCE}

Basically, Amazon.com is mainly looking for the customer-centric value proposition with more agility so that to drive the value to its maximum thus matching this value with the demands of today's highly competitive market (Amazon.com Inc., 2016).

\section{Amazon.Com Products \& Services}

Amazon.com products and services may be simply identified with 2 main groups as retails and non-retails. The retail part includes: Book, Music \& Movies, Consumer Electronics, Computer \& Office, Tools \& Automotive, Food \& Household, Home improvement, Toys \& Video Games, Sports \& Fitness, Clothing and Jewelry, Kids and Baby. While the non-retail part covers: Referrals / Commission base selling, Amazon Web Services (AWS), Fulfillment by Amazon. 24 brands positioning below illustrates the interrelated products \& services of Amazon.

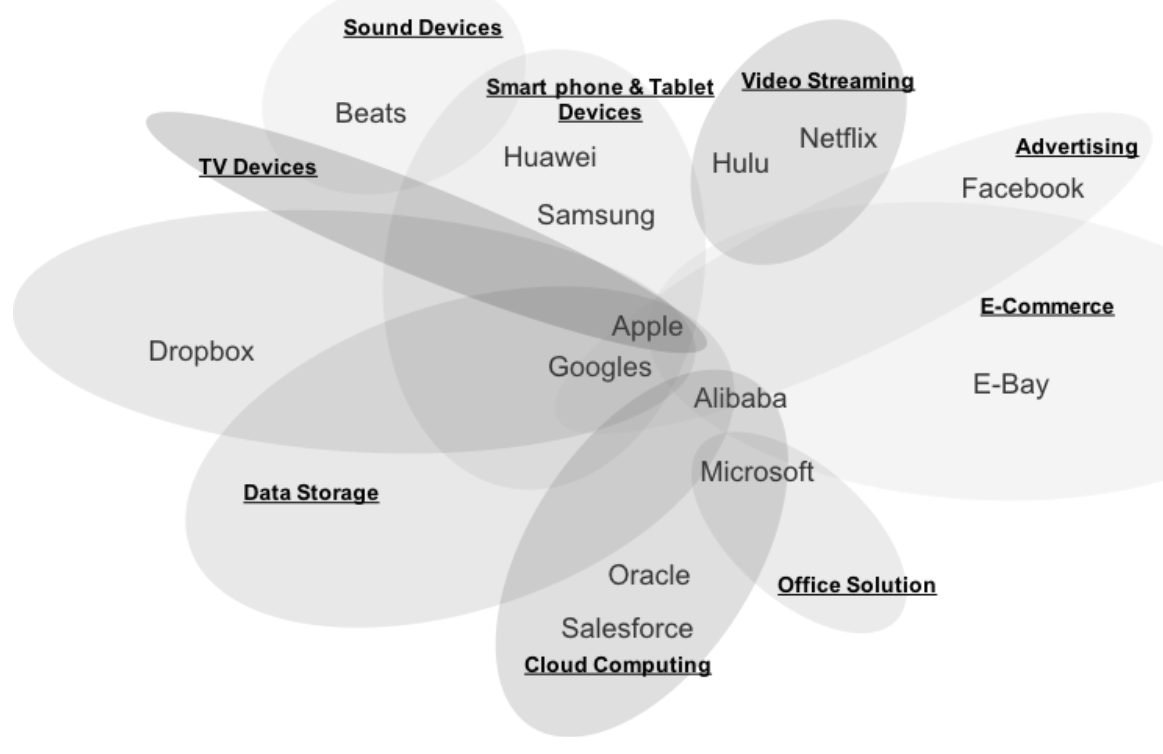

Figure 1. Amazon.Com Products \& Services

The figure above shows the Amazon.com business model canvas with its specific focus on the retail sector, Internet services, e-book ecosystem and platform business (Digital Business Models, 2016). This figure illustrates the keys partners, activities, value proposition, customer segmentation. From it, it is obvious that Amazon focuses on online retail. This has started from Amazon's detaching from traditional retailers to become a lowcost retailer. Next were the Internet services, Amazon Prime provides free two-day shipping on retails purchases, on-demands video streaming and also free access library for Kindle which is operating as a subscription business model. Moreover, Amazon Web services (AWS) include space leasing to other companies and individuals, with the core strategy being self-managing servers and other Internet services. Lastly, Amazon is expanding into the market of Kindle tablets manufacturing, providing tablet media services such as e-books online etc. (Digital Business Models, 2016). 


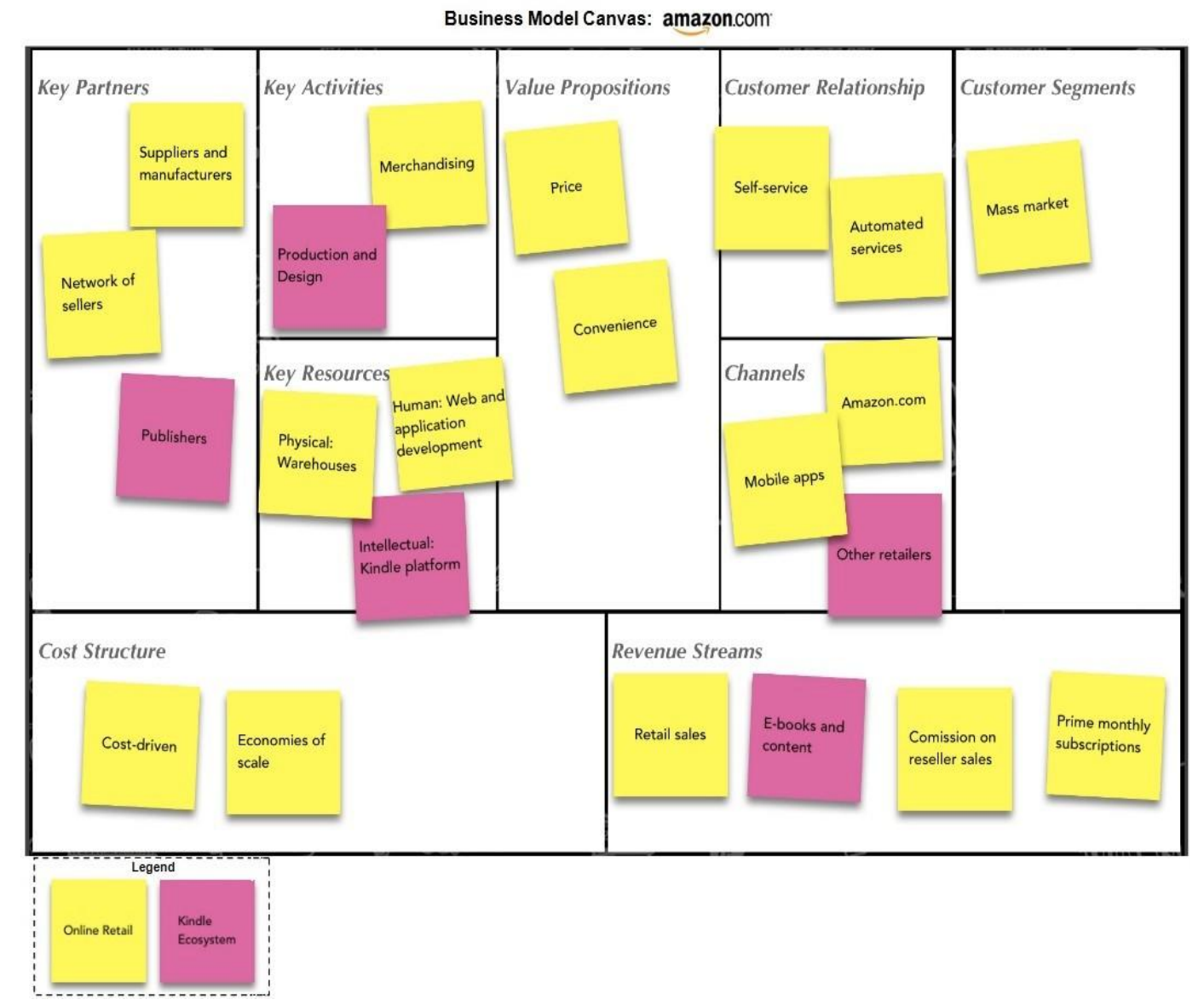

Figure 2. Business Model Canvas of Amazon.com

\section{Diversification and Acquisitions Of Amazon.Com}

Amazon.com has performed various diversifications, with both related and non-related business. The company has reinforced its retail business through non-related businesses, including the delivery system, groceries etc. Consequently, today Amazon.com is able to survive in many market areas at the same time.

\section{Internal Analysis}

\section{Value Chain Analysis: Porter's Generic Value Chain}

Porter's Generic value chain analysis is the methodology used to identify professional activity that can generate value along with a competitive advantage until value proposition is valid at a particular market. 


\section{STRATEGIC ANALYSIS OF GLOBAL E-COMMERCE}

Table 2.Value Chain of Amazon.Com

(analyzed by the coauthors)

\begin{tabular}{|c|c|}
\hline Value Factors & Consideration criteria \\
\hline Inbound Logistics & $\begin{array}{l}\text { Amazon does not have long-term agreement with any } \\
\text { merchandise, any special payment conditions or extension of a } \\
\text { credit limit. Amazon has however its own inbound logistics for } \\
\text { owned retails business which sellers can use for their inventory in } \\
\text { Amazon fulfilment centers. Amazon bear all responsibility for } \\
\text { logistics and all related services if a customer orders FBA and } \\
\text { Amazon own inventory goods (Schreiber, 2016) }\end{array}$ \\
\hline Operations & $\begin{array}{l}\text { In North America Amazon's sales increased by } 23 \% \text { back in } 2014 \\
\text { (Amazon.com, 2015) and then by } 25 \% \text { in } 2016 \text { (Amazon.com, 2016) } \\
\text { International market sales respectively increased by } 12 \% \text { back in } \\
2014 \text { (Amazon.com, 2015) and then by another } 24 \% \text { in } 2016 \\
\text { (Amazon.com, 2017). } \\
\text { AWS market growth was } 49 \% \text { in } 2014 \text { (Amazon.com, 2015) and } \\
55 \% \text { in } 2016 \text { (Amazon.com Inc., 2017). Web-services offer cloud } \\
\text { resources and computing services, while the current major } \\
\text { customers include Pinterest, Dropbox and Airbnb. Moreover, } \\
\text { building application platforms are provided to GE, Major League } \\
\text { Baseball, Tata Motors and Qantas. AWS offers more than 526 } \\
\text { features and services for more than } 1 \text { million customers altogether } \\
\text { (Amazon.com Inc., 2016) }\end{array}$ \\
\hline Outbound Logistic & $\begin{array}{l}\text { Amazon operates } 109 \text { centers around the world which are using } \\
\text { robotic technologies to manage receipt, stowing, picking and further } \\
\text { shipment. } \\
\text { Generally, Amazon entrusts its business deliveries to UPS, FedEx } \\
\text { and TNT but has also started to lease part of deliveries directly to } \\
\text { Boeing and Freighter (Forbes, 2015). }\end{array}$ \\
\hline Marketing \& Sales & $\begin{array}{l}\text { Annual global marketing expenses of the company in question have } \\
\text { been consistently increasing, going over } 7.2 \text { billion USD back in } 2016 . \\
\text { The marketing mix includes: printed ads, media advertising, } \\
\text { promotion, events and experience through various PR campaigns and } \\
\text { direct marketing. }\end{array}$ \\
\hline Services & $\begin{array}{l}\text { Amazon manages all of its services entirely online through customer } \\
\text { account, while support is partially provided via calls (Expert CRM } \\
\text { Software, n.d.). }\end{array}$ \\
\hline
\end{tabular}

\section{Competitive Advantage: Porter's Model}

Amazon's business canvas illustrates their strategy which mainly focuses on the competitive advantages related simulatenously to low cost and differentiation as broad as the mass market allows. Interestingly, their strategy fully complies with famous 4Ps by Philip Kotler.

As it is also evident from the business canvas model above, the emphasis as applied to the Porter's advantage strategy is on Amazon minimizing its operation costs which is 
partially evident from its advance computing and network technology operations, both being aimed at maximization of overall efficiency. The basis for e-commerce here is represented by the automatic systems which are usual for the processes of purchasing, scheduling, and operating, thus leading to minimization of operational costs at each of the stages (Simthson, 2017).

\section{Financial Insight}

Financial statement by Amazon clearly shows the company gained profitability at the end of 2016, however, its business trend at a particular point of time reached somewhat lower levels and then recovered back, mainly thanks to electronic devices' sales. Latest sales by Amazon evidence that a huge share of them belong to the group of Cell Phones \& Accessories, which together got 59.88 mln USD (Web Scraping Services, 2016).

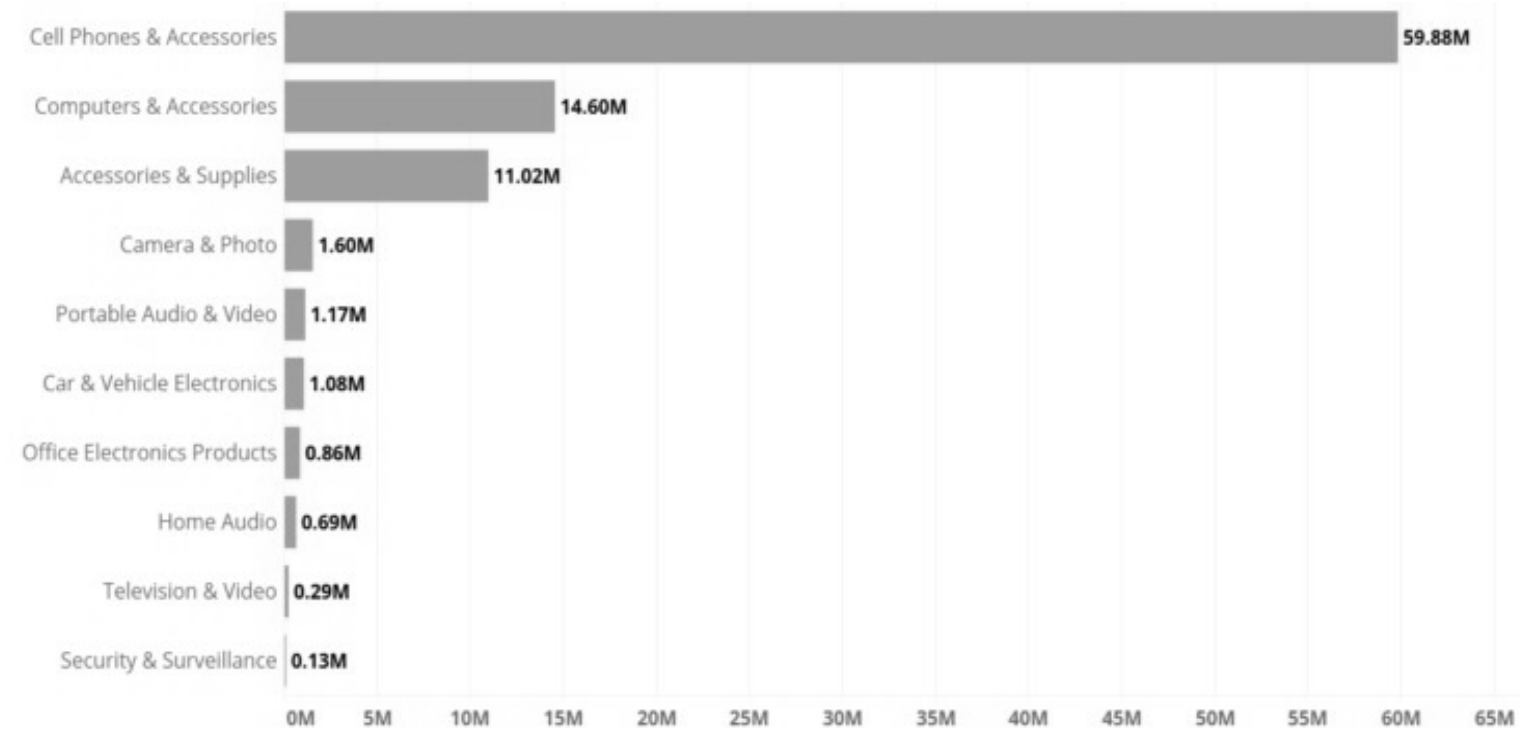

Figure 3. Amazon Electronic Market Revenues' Deepdive

(Source: https://www.scrapehero.com/how-many-products-are-sold-on-amazon-com-january-2017report/)

In the context of diversification by means of Mergers and Acquisitions (M\&A), it would be curious to compare Amazon with its closest competitors. This data reflects the key results from the acquisitions carried out by Amazon.com, since the latter is now able to reach the top level, quite comparable with Google. But the investment history overall also shows that \#1 in terms of M\&A deals still belongs to Google while the Amazon's trend goes moderaly up and down. 


\section{STRATEGIC ANALYSIS OF GLOBAL E-COMMERCE}

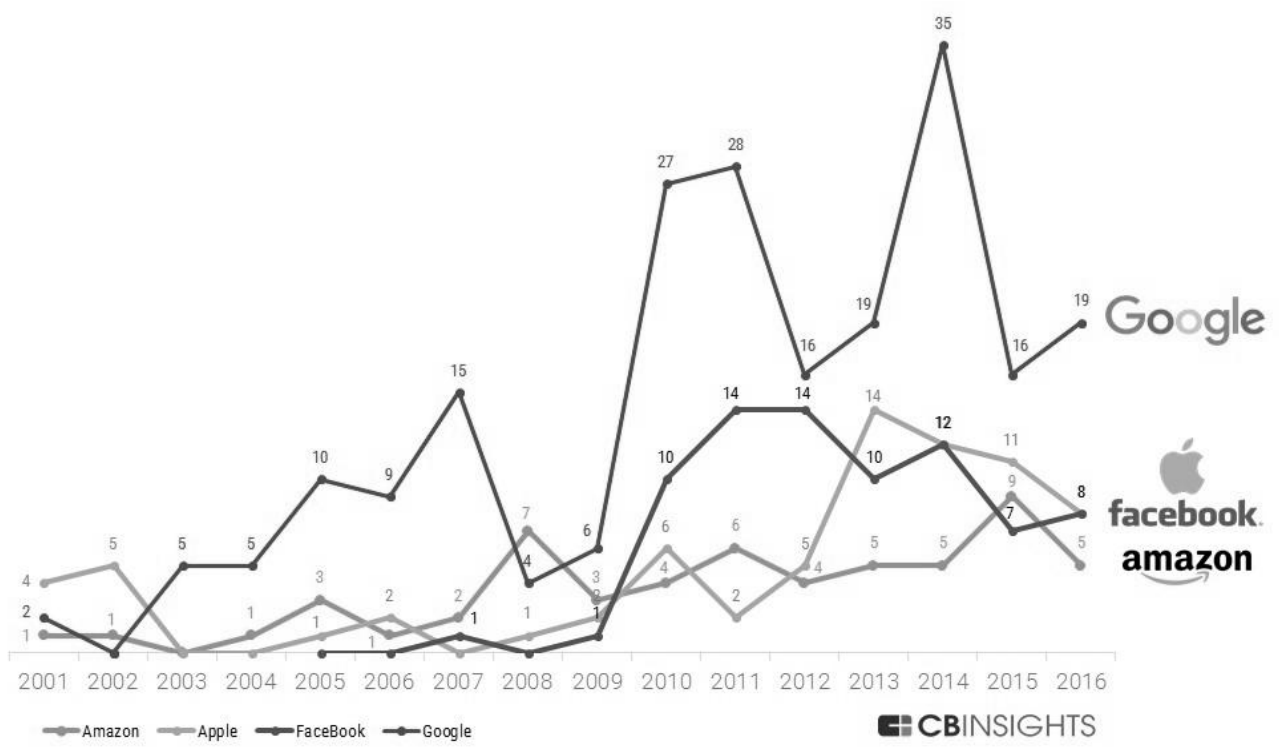

Figure 4. Revenues' Comparison in the context of Global Competition Viewed As Profit Contribution

(Source: https://www.cbinsights.com/research/report/amazon-strategy-teardown/)

\section{External Analysis}

\section{Pestle at International Markets}

PESTLE is another tool to assess external environment which combines political, economy, social, technological, environmental and legal aspects. It can be used for assessing the existing environment or reverse-back use for analyzing the influence of businesses on the external environment.

\section{Political}

Huge electronic retails like Amazon and e-bay can potentiall lead to many troubles from the political point of view, especially when it comes to Asian countries. One of such partially political, partially economic issues is taxation (Pratap, 2016). Amazon.com, however, manages well its both political and governmental influences. The company always gains benefits from the stability of political regimes since the latter usually creates an additional opportunity for the firm to enlarge or spread its business, especially in highly urbanized economies (Greenspan, 2017).

\section{Economic}

This is a significant factor influencing directly market conditions. E-retail rapidly grew by $23 \%$ back in 2015 , and this trend was characterized by broad market expansion. But this factor also made most of the related markets highly competitive (Pratap, 2016). Somehow, Amazon managed to maintain its positioning, taking into account the core trends of the macroenvironment development. Relative economic stability in the most of developed countries predetermined Amazon's success because online retails' business expansion and disposable income availability led to boosting of the company's financial performance. At 
the same time, recession in China is a threat because the new emerging competitor effects the revenue volumes of Amazon (Greenspan, 2017).

\section{Social}

Behind the scene of e-retails businesses, social and cultural trends are effecting their growth, though this is not always immediately obvious. Nowadays, the volume of mobile users is rapidly increasing, and this factor directly promotes further growth of the businesses like Amazon as they are expected to provide more convenience (Pratap, 2016).

At the same time, differences between the rich and the poor in so many countries worldwide threaten Amazon's success due to differences in the disposable income levels. However, the increasing demand in developing countries bring up the potential market development with its emphasis on more active online buying behavior. These are also additional opportunities stemming from the social climate (Greenspan, 2017).

\section{Technology}

The 21 st century is going to change IT technologies which already are the important factors of business encouragement. Innovation as such is a significant success factor in the modern era of better services' delivery. On the another hand, artificial intelligence and cognitive intelligence are gradually becoming the new competitive advantage, since both are able to provide better customer service and thus - more customer loyalty (Pratap, 2016).

Technologies' quick obsolescence forces companies continuously develop new technology assets, and this is a heavy load in terms of investments but also an opportunity in terms of differentiation and competitive advantage. For instance, newer technology can maximize productivity for e-commerce but it can also boost cybercrime at the same time, thus, any technology is always an opportunity to guarantee long-term survival, but for all parties involved (Greenspan, 2017).

\section{ENVIRONMENT}

Environment sustainability is a critical factor in the world development, and e-retail business is no exception in this regard. This business needs better packaging, with wastes' reduction, smarter energy consumption and other elements of business sustainability. This is directly linked to the investment in Corporate Social Responsibility (CSR) and strong dependency of many businesses on non-renewable energy (Pratap, 2016).

CSR activities, inter alia, contribute to satisfaction with a company and its marketing activity, while business sustainability contributes indirectly to standardization and stronger brand awareness and popularity of corporate image (Greenspan, 2017).

\section{LEGAL}

Compliance is important for global businesses, including Amazon. Any type of distribution concerns certain legal issues and challenges, including labor-related ones and many essential elements of legal compliance. It still a huge challenge for Amazon international business operations (Pratap, 2016). Interestingly, these challenges also tend to increase new opportunities. 


\section{STRATEGIC ANALYSIS OF GLOBAL E-COMMERCE}

Strengthening product regulation is creating new opportunities for Amazon in terms of intensifying and encouraging its battle to reduce counterfeit in the online retail sector. Also, the company has more chances to grow from easing import and export regulation. Moreover, the company has an opportunity to shape better brand image through its CSR activities so that to ensure long-term development of its e-commerce under full regulatory compliance (Greenspan, 2017).

\section{CURRENT SITUATION OF AMAZON.COM}

\section{SWOT Analysis}

The most known framework for assessment in the cases of both corporations or individuals is surely SWOT-analysis. We have decided to divide business situation and development area into two tables, see below.

Table 3. Strengths vs. Weaknesses

(offered by the coauthors)

\begin{tabular}{|c|c|}
\hline \multicolumn{2}{|c|}{ Strengths (S) } \\
$\begin{array}{c}\text { Reasonable price as compared to } \\
\text { the price and convenience } \\
\text { Technology orientation and value } \\
\text { preposition }\end{array}$ & $\begin{array}{c}\text { Slower growth of net margin as } \\
\text { compared to the closest competitors }\end{array}$ \\
$\begin{array}{c}\text { Various business dimensions that } \\
\text { encourage their own mutual } \\
\text { development }\end{array}$ & $\begin{array}{c}\text { Business diversification is not } \\
\text { directly beneficial for Amazon itself }\end{array}$ \\
\hline
\end{tabular}

Amazon's strengths start from value proposition as compared to the price, efforts and convenience. But in behind this strength, net profit margin of Amazon is always fluctuating, mostly due to frequent mergers and acquisitions and instability of business overall.

Amazon's opportunities correspond mostly with its own strengths of exploiting business shifts from technology development and unique product development such as Kindle. Broad differentiation is an additional encouragement factor in this regard. However, technologies are changing and developing very quickly. Thus, the cost of differentiation might decline in relation to pricing. At emerging markets cloud businesses become more and more widely spread, thus competition becomes quite severe. Therefore, any host country might come, at any time, with its new restrictions and rules which would kill all Amazon's expenditure into this particular country. 
Table 4. Opportunites vs. Threats

(offered by the coauthors)

\begin{tabular}{|c|c|}
\hline Opportunities (O) & Threats (T) \\
\hline $\begin{array}{c}\text { Exploiting the business shift to } \\
\text { cloud storage and diversification of } \\
\text { all related services }\end{array}$ & $\begin{array}{c}\text { Consumer hardware is supposed } \\
\text { to improve while prices are only } \\
\text { declining -this means that e- } \\
\text { kindle e-book conquered } \\
\text { only a small part of the } \\
\text { publishing industry and the } \\
\text { audiobooks' sector }\end{array}$ \\
$\begin{array}{c}\text { Cloud business is getting more } \\
\text { and more competitors, and there } \\
\text { leading position today but } \\
\text { are a lot of newcomers at this } \\
\text { also have a chance for } \\
\text { further business } \\
\text { diversification }\end{array}$ & $\begin{array}{c}\text { Internet payment services would } \\
\text { have to compete with local } \\
\text { providers across the world }\end{array}$ \\
\end{tabular}

\section{Porter's Five Forces Analysis}

Porter's Five Force is a generic principle for assessing the current position at a particlar market.

\section{Table 5 - Amazon's Five Force Analysis \\ (compiled by the coauthors)}

\begin{tabular}{|l|l|}
\hline $\begin{array}{l}\text { Threat of } \\
\text { - High entrants }\end{array}$ & $\begin{array}{l}\text { Online business as such is too valuable for Amazon. New market } \\
\text { entrants will have no problems since there is quite a variety of logistic } \\
\text { provider such as DHL, TNT, UPS and others. This factor has its } \\
\text { critical impact on Amazon business in the context of new entrants at } \\
\text { the market (Dudovaskiy, 2017) }\end{array}$ \\
\hline $\begin{array}{l}\text { Threat of } \\
\text { substitute } \\
\text { products and } \\
\text { services - High }\end{array}$ & $\begin{array}{l}\text { From the standpoint of customers, there are many types of products } \\
\text { and services Amazon is offering today. However, there is also an } \\
\text { alternative variety of physical stores as well as other websites that } \\
\text { could easily replac or substitute Amazon (Dudovaskiy, 2017). }\end{array}$ \\
\hline $\begin{array}{l}\text { Bargaining power } \\
\text { Highazon buyer - }\end{array}$ & $\begin{array}{l}\text { The bargaining power of buyers from varies sectors of customers is } \\
\text { increasing because it easily changes from Amazon to any other } \\
\text { substitute that is why price is a highly sensitive and significant factor } \\
\text { for the Amazon strategy (Dudovaskiy, 2017). }\end{array}$ \\
\hline $\begin{array}{l}\text { Bargaining power } \\
\text { of suppliers - } \\
\text { moderate }\end{array}$ & $\begin{array}{l}\text { Amazon has small population of suppliers which has a relatively } \\
\text { strong force but moderation effect influences their integration size of } \\
\text { supplier while the size reduce the force until it becomes moderate } \\
\text { (Greenspan, 2017). }\end{array}$ \\
\hline $\begin{array}{l}\text { Rivalry among } \\
\text { the already } \\
\text { existing similar } \\
\text { firms - High }\end{array}$ & $\begin{array}{l}\text { Retail businesses are quite aggressive in relation to each other due to } \\
\text { rather strong competition at the market. The strongest competitor of } \\
\text { Amazon today is Walmart which has a very strong background in the } \\
\text { retail sector and is expanding into e-commerce quite intensively } \\
\text { (Greenspan, 2017). }\end{array}$ \\
\hline
\end{tabular}




\section{STRATEGIC ANALYSIS OF GLOBAL E-COMMERCE}

The five-forces analysis of the Amazon business seems be a difficult task despite many forces being the critical factors at the same time. Amazon still survives in the market but it needs to develop technologies constantly and provide business diversification continuously.

\section{BCG matrix}

Yet another interesting analysis tool to determine a business position is BCG. The illustration below shows the Amazon's product position and description according to this methodology.

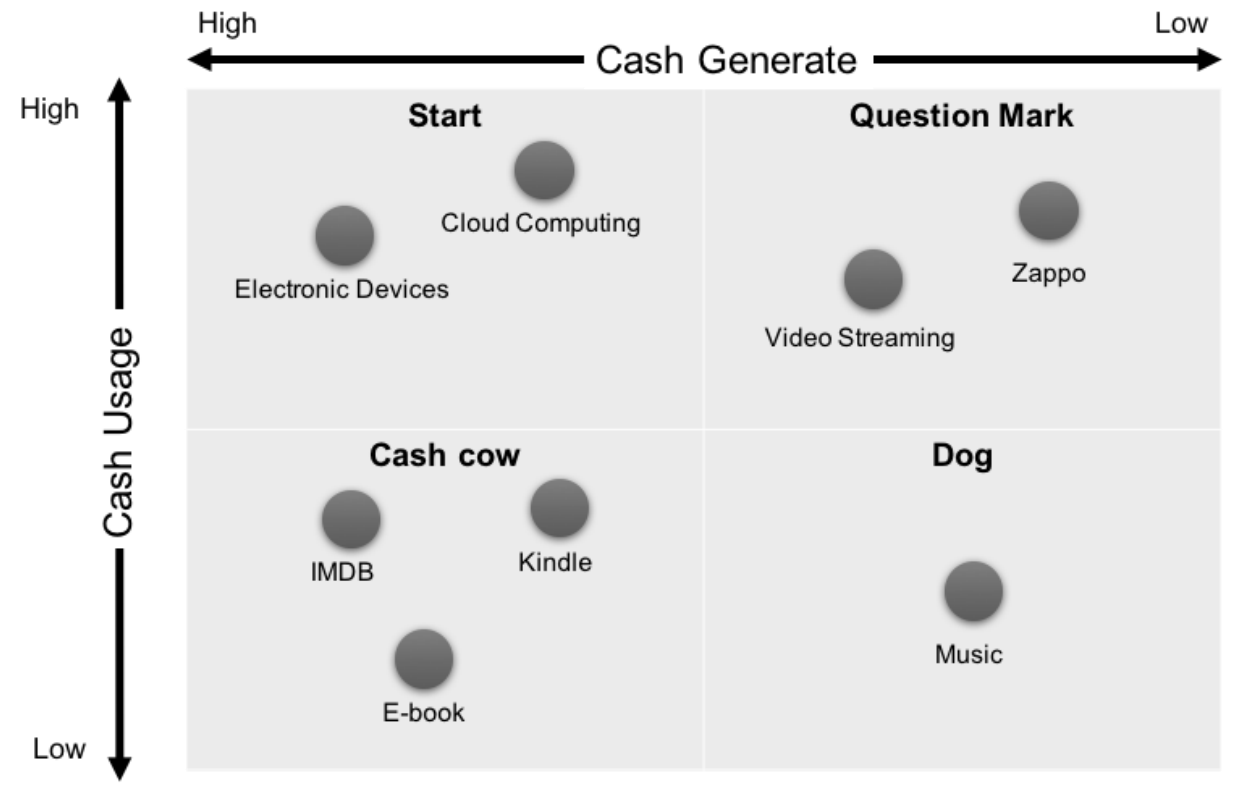

Figure 5. BCG Matrix Of Amazon.Com

Cash cow, it is first quadrant shows that the low cash usage but high cash generate were identified in relation to Kindle e-books and IMDB. Revenues from e-book selling were observed to increase significantly over the years, while the number of Kindle's users wa ts expanding, thus making it a high-value product for Amazon (Miller \& Bosman, 2011). Audio books were roughly at the same level with the e-book markets, that is, also demonstrating quite impressive sales. In addition, on-demand movie streaming has also generated high revenues (Adamkasi, 2017).

Start, this is the secondary category of products and the assertion of Amazon's financial performance, has achieved higher sales as compared to brick \& mortar retails such as the Best buy (Griswold, 2016). This trend is further expected to increase due to increasing number of users at the online shopping portals. In addition, the cloud computing segment has shown positive growth prospects for the near future, hinting that this product may become a cash cow in future once a relatively significant level of market share is established (Adamkasi, 2017).

Question Marks - this quadrant shows the chance of growing into a profitable business. The segment of video streaming demand has some problems with connectivity, and Zappos has faced similar problems due to its low maturity and low rate of return after its acquisition by Amazon (Stone, 2009). These businesses will need to solve these issues which so far have resulted in low market share, thus, these units need to become more profitable (Adamkasi, 
2017). But already now, these businesses do not belong to the Start quadrant because video on demand is starting to gain more market share as people's behavior and buying habits are changing when it comes to video these days.

Dogs, this quadrant of the matrix is usually for those products that are not able to generate high revenues and thus have a notable market share. For Amazon music business has not been able to provide solid financial leverage (Adamkasi, 2017) that is why MP3 business is in the Dogs part of the BCG matrix.

Due to space limitations this figure cannot illustrate all of Amazon's products and services. Only the major items are thus presented there.

\section{VRIO framework}

VRIO framework gives us a chance to describe the company in question in comparison with its direct competitor, in this case - google. At first glance, it may seem that Google and Amazon have a similar strategy but as the book postulates, "three aspects of Google's search products initially gave it an advantage over other search engines". These three features are: "(1) the way that it evaluates the quality of websites in response to a search request, (2) the way that it interactes with firms seeking to advertise in conjunction with searches, and (3) its price for consumers". Moreover, Google imposes "aggressive yet incredibly creative culture," (DPTHRNBR, 2017), and this is actually quite similar to Amazon.

But Amazon has an extremely aggressive style and also an innovate approach to accessing different market areas. Amazon established itself as the main player in the industry that has a truly mass customer base. What is interesting here is that Amazon has the capability to attract people with valuable products, rare things and also low-cost orientation (DPTHRNBR, 2017)

\section{Current Market Position}

Today's market position reveals the current Amazon's strategy and positioning.

Amazon's market development strategy is primarily concentrated to entering new markets and growing on promising young markets. By now, Amazon has developed its retails services to consumers at 10 markets/in 10 countries. This activity is following the vision of global market outreach (Simthson, 2017).

Market Penetration is a secondary growth strategy for Amazon's online retail business which Amazon develop to intensify the interest in online retails. The company gains benefits from higher revenues due to rapid growth population based on low cost competitive advantage and its rather aggressive marketing campaign via Amazon's website (Simthson, 2017).

In part of Product Development, Amazon focuses on supporting customer functionalities which generate differentiation of competitive advantages. Development and offering new products accelerate revenues such Amazon Web Services (AWS) which cost leadership support comprehensive growth to mature research and development (R\&D) investment for rapid product development (Simthson, 2017).

Diversification is a significant part of intensive growth for Amazon. For example, Audible was acquired to expand the e-book sector onto audiobooks and the related products. Correspondingly, Amazon also attract more customers due to its cost leadership as Amazon's 


\section{STRATEGIC ANALYSIS OF GLOBAL E-COMMERCE}

core competency is gainining new market shares through aggressive acquisition (Simthson, 2017)

\section{Vision and Mission in Relation to Competitors}

Amazon.com business overall has been identified as 3 segments, each having its potential and current competitors.

\section{E- Retail Business}

In the e-retail business, Amazon faces serious competitors from e-bay and Walmart, both having a competitive advantage due to low-cost factor. Additionally, there are server competitors in the field of electronic and general commerce ready to compete. These include: Best buy, Family Dollar, RadioShack, Staples, Target, Walmart, Sears, Big Lots, Delia and Systemac. Moreover, speaking internationally, the competition also includes Ailbaba Group, LightInTheBox Holding Co., Overstock.com, PCM, Vipshop Holding, JD.com, Wayfair Inc. and Zuilly. These are quite active online merchandising platforms market with significant potential for growth. Amazon must verify regularly it still has enough competitive advantage to resist these quite strong competitors (Investopedia, 2017).

\section{Electronic Devices, E-Book Ecosystem And Media Segment}

At the electronic devices market, Kindle is the main device that Amazon releases as it has its unique identity. But the main competitor is Apple, and it has many functionality devices such as iPad with its iTunes services. At this market, Amazon must consider additional investment in functionality to compete with Apple Inc. (Investopedia, 2017).

In the segment of e-books and audiobooks, Amazon does not have many competitors. On the other hand, there are many new competitors that are still developing and already trying to gain their market share of this business.

Media segment demonstrates the highest rate of competition at this market overall because there are already quite many competitors such as E-Bay, Netflix, Warner Cable, Apple, Google Play and also minor players.

\section{Internet Services}

Within this operating segment, Amazon competes with such global companies as CDW, PC Connection, Insight Enterprise, Google, Oracle and in parallel to that, it also competes with Salefoce.com, Accenture and Citrix System in the apps segment (Investopedia, 2017).

Gartner magic quadrant assigns Amazon as the leader of this market segment, however, Microsoft is gaining its market share due to Office 365 popularity which is increasing day by day.

\section{Future Strategy}

Referring to the business canvas already presented above, Amazon is able to offer a value proposition in terms of both price and convenience to ensure continuous customer relationship under self-service automation. Most probably, Amazon will continue to expand focusing on these 2 building blocks (Digital Business Models, 2016). 


\section{Low-cost orientation and maximization}

Amazon publishing is one of the most recent ventures of this company providing the tools for on-demand publishing and giving new authors access to the Amazon store. This extension of Amazon publishing is likely to cause some troublemaking in the industry eventually (Digital Business Models, 2016).

\section{Maintaining revenues from the electronic devices segment diversifying it at the same time}

The segment of electronic devices has the highest competition with quite many market leaders such as Apple Inc., Huawei, Google. Anyway, the latest statistics on revenues in this segment clearly shows that electronic devices are still able to provide the highest revenue and rapidly accumulate net profit. But the value proposition of Amazon could not compete here in the long run, especially when being compared with the leader - the Apple. Also, Amazon might eventually find it difficult to compete with Chinese Huawei due to the low cost the latter is offering. That why this business line needs to be on high alert in terms of maintaining the market position with potential reconsideration of direction for investment and competitive advantage position.

\section{Expand services and satisfaction areas using previous investments}

The Amazon's revolution in delivery in some parts of the US is a real challenge for all other online merchandisers. And Amazon today is quite able to transform its business even further applying Amazon's own technologies development (Digital Business Models, 2016).

Moreover, its market dominance will continue in the near future too as Amazon explores new product and services categories in which this company has clear expertise in terms of e-commerce innovation. Moreover, it is able to apply a variety of traditional business model in the context of digital transformation (Digital Business Models, 2016).

\section{Diversification as codevelopment of the competitive advantages}

One of the drawback from mergers and acquisitions carried out by Amazon is that it could take some time and efforts to align all these businesses to each other. But Amazon must in any case converge its technologies and competitive advantages before the next wave of M\&As which would most probably cover logistic integration systems and expanding the coverage onto new countries (CBInsights, 2017). This will have its effect on the financial statementa and complexity of operations too.

\section{Differentiation of services driven by AI}

The lately released service by Amazon is AutoRip which is a music merchandise operating in a cloud. There is also an expectation that this services may be later enlarged onto movies and books, and later - on allowing also purchases of physical (Digital Business Models, 2016). This emerging market is already highly competitive. Amazon needs to build a brand new business pillar for that which another pillar, both being convergent and divergent from other Amazon businesses by means of Artificial Intelligence (AI).

This is only one example of cloud service diversification on which Amazon must focus in the course of its continuous development. 


\section{STRATEGIC ANALYSIS OF GLOBAL E-COMMERCE}

\section{Conclusion}

There are numerous arguments and comments from various sources mentioned Amazon.com business in its many diversifications. But it is already evident that emerging markets and newer business segments are pushing forward new competitors for Amazon. Thus, the company will have to broaden its development strategy in every single business area, specifying more clearer the direction in which Amazon is planning to maintain its competitive advantages so that only to survive and but also keep its leading market position.

\section{References:}

Adamkasi. (2017, Apr 27). BCG Matrix of Amazon. Retrieved from BCG Matrix Analysis: http://bcgmatrixanalysis.com/bcg-matrix-of-amazon/

Amazon.com. (2015). 2014 Annual Report. Amazon.com.

Amazon.com. (2017). 2016 Annual Report. Amazon.com.

Amazon.com Inc. (2016). 2016 Amazon.com annual report. Retrieved from Amazon - Investor Relations: https97664\%26p\%3Dirol- reportsannual\&usg=AFQjCNHhRpojgMCtOwg LtohorihHDd3F0g

Canvanizer. (2016). Create a new Business Model Canvas. Retrieved from Canvanizer: https://canvanizer.com/new/business-model-canvas

CBInsights. (2017). Amazon Strategy Teardown: Building New Business Pillar In AI, Next-gen Logistic and Enterprise Cloud Apps. Retrieved from CBInsights: https://www.cbinsights.com/research/report /amazon-strategy-teardown/

Chaffey, D. (2014, Jun 30). Amazon's business strategy and revenue model: A history and 2014 update. Retrieved from Smart Insights: http://www.smartinsights.com/digital-marketingstrategy/online- business-revenue-models/amazon-case-study/

Digital Business Models. (2016, Jul 08). Analysis of the Amazon Business Model. Retrieved from Digital Business Model: http://www.digitalbusinessmodelguru.com/2013/07/analysis-ofamazon- business-model.html

DPTHRNBR. (2017, Feb 19). Chapter 5 Analysis: Applying the VRIO Framework to Amazon. Retrieved from MGNT 7160: Amazon Blog by Dillon: https://mgmt7160.wordpress.com/2017/02/19/chapter-5-analysis-applying-the-vrioframework-to-amazon/

Dudovaskiy, J. (2017). Amazon Porter's Five Force Analysis. Retrieved from Research Methodology: https://research-methodology.net/amazon-porters-five-forces-analysis/

Expert CRM Software (n.d.). Amazon CRM Case Study. Retrieved from Expert CRM Software: https://crmsystems.expertmarket.co.uk/Amazon-CRM-Case-Study

Farfan, B. (2017). Amazon.com's Mission Statement. Retrieved from The Balance: https://www.thebalance.com/amazon-mission-statement-4068548

Forbes (2015). Will UPS, FedEx Lose Out To Amazon? Retrieved from Forbes: https://www.forbes.com/sites/greatspeculations/2015/12/29/will-ups-fedex-lose-out-toamazon/\#1688a3935ca6

Fortune 500 (2016). Full List. Retrieved Sep 13, 2017, from Fortune 500: http://fortune.com/fortune500/list/

Fortune 500 (2017). The World's Most Innovative Companies \#3 Amazon.com. Retrieved from Fortune 500: https://www.forbes.com/companies/amazon/

Greenspan, R. (2017). Amazon.com Inc. PESTEL/PESTLE Analysis, Recommendations. Retrieved from Panmore Institue: http://panmore.com/amazon-com-inc-pestel-pestleanalysis- recommendations 
Gregory, L. (2017). Amazon.com Inc. 's Vision Statement \& Mission Statement (An Analysis). Retrieved from Panmore Institute: http://panmore.com/amazon-com-inc-visionstatement- mission-statement-analysis

Griswold, A. (2016). Amazon will soon dethrone Best Buy as the top seller of consumer electronics. Retrieved from Quartz: https://qz.com/712709/amazon-will-soon-dethronebest- buy-as-the-top-seller-of-consumer-electronics/

Gupta, S. (2017). 3 Ways Amazon CEO Jeff Bezos Makes Tough Decisions Without Being 100\% Sure. Retrieved from Fortune.com: http://fortune.com/2017/05/11/jeff-bezosshareholder-letter/

Hanlon, A. (2017). How to use the BCG Matrix. Retrieved from Smart Insights: http://www.smartinsights.com/marketing-planning/marketing-models/use-bcg-matrix/

Kotelnikov, V. (2008). Amazon.com. Retrieved Sep 10, 2017, from 1000 Venterures Breakthrough e-Coach: http://www.1000ventures.com/business_guide/ cs_biz_model_amazon.html

Miller, C. C., \& Bosman, J. (2011). E-Book Outsell Print Books at Amazon. Retrieved from The New York Times: http://www.nytimes.com/2011/05/20/ technology/20amazon.html

Mohan, M. (2016). All Things Amazon: A List Of Over 21 Amazon Products \& Services.

Retrieved from Minterest: https://www.minterest.com/all-things-amazon/

Pratap, A. (2016). Amazon Pestel analysis. Retrieved from Cheshnotes: https://www.cheshnotes.com/amazon-pestel-analysis/

Schreiber, Z. (2016). Is Logistics About To Get Amazon'ed? Retrieved from Tech Crunch: https://techcrunch.com/2016/01/29/is-logistics-about-to-get-amazoned/

Sharwood, S. (2017). Gartner confirms what we all know: AWS and Microsoft are the cloud leaders, by a fair way. Retrieved from The register Biting the hand that feeds IT: https://www.theregister.co.uk/2017/06/19/gartner_confirms_what_we_all_know_aws_and _mi crosoft_are_the_cloud_leaders_by_a_fair_way/

Simthson, N. (2017). Amazon.com Inc.'s Generic Strategy, Intensive Growth Strategies. Retrieved from Panmore Institue: http://panmore.com/amazon-com-inc-generic-strategyintensive-growth-strategies

Stone, B. (2009). Amazon's Expanding With Deal for Zappos. Retrieved from The New York Times: http://www.nytimes.com/2009/07/23/ technology/companies/23amazon.html?_r=0

Web Scraping Services. (2016). 398 Million products are sold on Amazon.com. Retrieved from Web Scraping Services: https://www.scrapehero.com/how-many-products-are-sold-onamazon-com-january-2017-report/

Paper submitted

Paper accepted for publishing

Paper published online
04 September 2017

12 November 2017

01 February 2018 